\title{
Unknown Regimen
}

National Cancer Institute

\section{Source}

National Cancer Institute. Unknown Regimen. NCI Thesaurus. Code C157516.

An indication that the treatment regimen used is not known. 